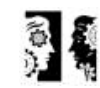

editorials

\section{References}

ADAMS, C. \& GILBODY, S. (2001) "Nobody ever expects the Spanish Inquisition" (Python, 1991). Psychiatric Bulletin, 25, 291-292.

BEBBINGTON, P. (2001) Choosing antipsychotic drugs in schizophrenia. A personal view. Psychiatric Bulletin, 25, 284-286.

HAAS, G. L., GARRATT, L. S. \& SWEENEY, J. A. (1998) Delay to antipsychotic medication in schizophrenia. Impact on symptomatology and clinical course of the illness. Journal of Psychiatric Research, 32, 151-159.

HEALY, D. (2001) Evidence biased psychiatry? Psychiatric Bulletin, 25, 290-291.

HOGMAN, G. (2001) National Schizophrenia Fellowship on treatment guidelines. Psychiatric Bulletin, 25, 289-290.

KERWIN, R.W. (1996) An essay on the use of new antipsychotics (with commentary response byT. R. E. Barnes). Psychiatric Bulletin, 20, 23-29.
LIEBERMAN, J. A., JODY, D., GEISLER, S. H., et al (1993) Time course and biological correlates of treatment response to first episode schizophrenia. Archives of Genera Psychiatry, 50, 369-376.

MORTIMER, A. M. (2001) First-line atypical antipsychotics for schizophrenia are appropriate - with psychosocial interventions. Psychiatric Bulletin, 25, 287-288.

Robert Kerwin Head of Clinical Neuropharmacology, Division of Psychological Medicine, Institute of Psychiatry, De Crespigny Park, London SE5 8AF

Psychiatric Bulletin (2001), 25, 282-283

\title{
Dangerous severe personality disorder: from notion to law ${ }^{\dagger}$
}

The Government's legislative proposals on dangerous severe personality disorder (DSPD) are set out in its comprehensive White Paper on mental health law reform, published last year (Department of Health \& Home Office, 2000). It includes ambitious plans for the piloting of an entirely new service for the assessment and treatment of DSPD. Whether there will be any positive effect on public safety that is either measurable or confidently attributable to the proposed law may never be known.

Under the unashamed banner of public protection, Part II of the White Paper sets out the arrangements for those who are said to be DSPD (a term now used as both noun and adjective). In the Government's brave new world any citizen with, or suspected of being, DSPD will be liable to indefinite incarceration through a care and treatment order imposed by a mental health review tribunal (MHRT) or a court. Suspected cases can be selfreferred or recommended for preliminary examination by a carer, general practitioner, criminal justice agency (police, probation, courts or prison service) or under a special power of the Home Secretary.

The arrangements will be a modification of those for the compulsory assessment and treatment of patients with other types of mental disorder. Preliminary examination will be followed by a 'DSPD screening assessment' carried out by a small specialist team in a 'suitable regional NHS secure facility'. If there is sufficient evidence of DSPD the patient will be transferred to a designated specialist centre for 'intensive assessment' carried out over 3 months. A MHRT will then authorise detention for specialist care and treatment, again in a specialist facility. Confirmed cases of DSPD must be detained for treatment but discharge from detention depends on a test of public safety rather than responsiveness to treatment.

Cutting through all the White Paper's promises of resources, service developments, training, standard setting and evaluation, psychiatrists will identify three consequences of this legislation. First, the law will permit lifelong detention in hospital of people facing no criminal charges but whose alleged type of personality disorder places them at risk of dangerous offending in the future. Second, the only means of extending the incarceration of a dangerous prisoner with alleged personality disorder beyond the maximum imposed by the sentencing judge will be by detention in a hospital under mental health law. Third, psychiatrists, particularly forensic psychiatrists, will have crucial roles in carrying out the assessments; advising the new MHRTs; and contributing to treatment. It may be possible for them to sidestep the new role of clinical supervisor but that role, at least for DSPD patients, will essentially be titular: crucial decisions will be taken elsewhere.

The reforms will not apply in the two parts of the UK with the highest homicide rates, Scotland and Northern Ireland. Indeed, the Scottish Executive, which has sole legislative power on this matter north of the border, has recently published its White Paper (Scottish Executive, 2001) on serious violent and sexual offenders. Legislation will be based on the findings of the MacLean Committee (Scottish Executive, 2000) and include special sentencing procedures for all serious offenders, including those with any type of mental disorder, based on a comprehensive assessment of risk rather than on possession of any particular type, or putative type, of psychiatric condition. DSPD legislation has no power whatsoever over those who are dangerous, for example as a consequence of alcohol or other substance misuse, but who do not have personality disorders.

Will forensic psychiatrists cooperate in sufficient numbers to make it all work? Haddock et al (2001, this issue) surveyed consultants and senior trainees in forensic psychiatry after publication of the DSPD consultation paper (Home Office \& Department of Health, 1999), but before that of the White Paper. Only one in three doctors think that severe personality disorder is an identifiably distinct condition, and $82 \%$ of respondents consider that current risk assessment procedures are unsatisfactory for diagnostic purposes. Less than one in five respondents 
think that psychiatrists should take a lead role in the services and a similar proportion are willing to work in them. This feeble support, if translated into action, may, however, be sufficient for the Government to achieve its aim of piloting the assessment procedure and initiating treatment at an anticipated rate of 140 secure NHS places by April 2004.

Parliament will soon be asked to approve a mandatory, but unestablished, assessment procedure for a condition that, by the Government's admission, is not yet defined so that an as yet undiscovered treatment can then be administered. The Government has created a personality disorder monster that the public wish to see slain and we can expect Members of Parliament dutifully to approve the legislation. They should pause to heed Walker \& McCabe's observation on the history of psychopathy: when a notion "in the minds of philosophers and mad-doctors" becomes an ill-defined term of art that is then "bundled into the statute-book", the resulting trouble "takes half a century to recognise and remedy, and ... it remains uncertain whether the remedy is entirely successful" (Walker \& McCabe, 1973).

\section{References}

DEPARTMENT OF HEALTH \& HOME OFFICE (2000) Reforming the Mental Health Act, Parts I and II. Cm 5016-II. London: Stationery Office.

Development. London: Home Office \& Department of Health.

SCOTTISHEXECUTIVE (2000) Report of the Committee on Serious Violent and

HADDOCK, A. SNOWDEN, P., DOLAN, Sexual Offenders. SE/2000/68. M., et al (2001) Managing dangerous Edinburgh: Scottish Executive. people with severe personality disorder: a survey of forensic psychiatrists'opinions. Psychiatric Bulletin, 25, 293-296.

- (2001) Serious Violent and Sexual Offenders: Criminal Justice. Edinburgh: Scottish Executive.

HOME OFFICE \& DEPARTMENT OF

HEALTH (1999) Managing Dangerous People with Severe Personality

WALKER, N. \& MCCABE, S. (1973) Crime and Insanity in England. Volume II: New Solutions and New Problems.

Disorder: Proposals for Policy Edinburgh: University Press.

Derek Chiswick Consultant Forensic Psychiatrist, The Orchard Clinic, Royal Edinburgh Hospital, MorningsideTerrace, Edinburgh EH10 5HF 